Journal of Management and Development Studies

Volume: 30, Issue 1, 37-50

(C) 2021 Nepal Administrative Staff College

Article Link: https://doi.org/10.3126/jmds.v30i1.36350

https://www.nasc.org.np/journals/all

ISSN 2392-4896 online/ ISSN 2392-4888 print

\title{
Remittances and development in Nepal: A disaggregated analysis
}

\author{
Shiva Hari Adhikari \\ Nepal Administrative Staff College \\ shiva.adhikari@nasc.org.np
}

\begin{abstract}
Remittance flows into low/middle-income counties are on a continuous rise and this trend is seen in Nepal as well. There is a constant increase in the number of the Nepalese workers migrating for foreign employment and that has been instrumental to boost the remittance inflow into the country. Remittance is contributing significantly to Gross Domestic Product and is emerging as a backbone of the country's economy. However, the ways remittances contribute to social development necessitates that many facets of development be explored because they affect the country's development in multiple ways. This study attempts to analyse the possibility that remittance positively contributes to social development, considering health and educational development as its proxies. Based on the latest available disaggregated educational enrolment and nutrition data of 2009 A.D. by districts, this study analyses the impact of the remittances on school enrolment and improvement in health status of families who remain at home. The results show a significant relationship between remittance and school enrolment but it also shows an insignificant relationship between remittance and health. The findings may be of interest to the countries and the policy makers with remittance being the dominant source of foreign currency. As the results of this study have indicated that remittances may serve as a contributing factor to the educational enrolment for social development.
\end{abstract}

Keywords: remittance, social development, school enrolment, malnutrition 


\section{Introduction}

Remittance is a major source of foreign exchange earnings in many low and middle income countries $(\mathrm{LMICS})^{1}$, and are on the rise. In 2018, remittance flows to LMICs reached \$529 billion, an increase of 9.6 percent over 2017 (World Bank Group, 2019). With the continuous rise in the transfer of money and goods sent by migrant workers, remittance is now gathering huge attention in global forums across the world. For example, remittance is recognized as one of the indicators of Sustainable Development Goals (SDGs), and the discussion on helping remittance-receiving families leverages the positive impact on development (International Fund for Agricultural Development, 2017) which is constantly evolving. Remittance is now considered equally important as foreign direct investment, official development assistance and international trade for development activities because the amounts of remittances flowing to LMICs are now more than three times the size of official development assistance and higher than the foreign direct investment (World Bank Group, 2019).

The SDG's target 17.3 mobilizes additional financial resources for developing countries from multiple sources. It has two indicators; and the volume of remittance as a proportion of total Gross Development Product (GDP) is defined as one of the two indicators. (Inter-Agency and Expert Group on Sustainable Development Goal Indicators, 2016). With the incorporation of remittance as one of the indicators into SDGs, national governments have acknowledged the importance of remittance and the way it shapes the development outcomes. Subsequently, the remittance sent by a migrant worker to his/her family back to the country is considered as vital to reach the SDGs commitments because it contributes significantly as a support for hundreds of millions of people across the globe. International Fund for Agricultural Development (2017) suggests that the fundamental contribution of migrant workers to their families and communities and to the sustainable development of their countries of origin be duly acknowledged.

From the time when remittance became a global agenda, it started to generate more strategic importance for governments, policy makers, academics and other partners which was not the case in the Millennium Development Goals, a predecessor of SDGs, Countries, at least the LMICs, might regard remittance as one of the most secure and reliable sources of foreign currency. However, limited discussions and explorations are taking place regarding productive use and potential development impact of migrants' remittances. There is no controversy in claiming that remittance has also an impact on increased consumption. Nevertheless, the impact of remittances on health and education is still under-ploughed and these areas have become a concern among the academia and policymakers.

Like other LMICs, Nepalese economy is increasingly becoming dependent on remittance sent by the migrants who are involved in foreign employment. Nepalese migrant workers are strongly connected with their family members; so they send back considerable amount of remittance. Nepal is one of the top remittance-receiving countries as a share of gross domestic product. According to the World Bank, remittance accounted for 28\% of Nepal's GDP in 2018, which ranked Nepal as the world's $5^{\text {th }}$ remittance receiver (World Bank Group, 2019). The considerable inflow

1 World Bank classifies countries/economies in four groups according to gross national income per capita. The groups are: low income, $\$ 1,025$ or less; lower middle income, \$1,026 - 3,995; upper middle income, \$3,996 - 12,375; and high income, $\$ 12,375$ or more. 
of remittance has increased its share of country's economy from 2\% of GDP in 2001 to $28 \%$ in 2018. For example, remittance income has contributed significantly in reducing the poverty head count. Central Bureau of Statistics (CBS) (2011) states that remittance income has contributed in reducing the poverty head count from $42 \%$ in 1995 down to $25 \%$ in 2010 . Then focus now should be on mobilizing remittance and ensuring proper utilization of such transfers. Studies of Pant (2011), Devkota (2014) and Ministry of Labour and Employment (MoLE) (2016) have also stressed on the need of the proper utilization of the remittance in Nepal. But, is the increasing amount of remittance inflows contributing to the social development in Nepal?

This paper aims to examine the contribution of remittances to the social development, considering health and educational development as its proxies. Through this study, an attempt has been made to determine the impact of migrant remittances on the improvement of nutritional status and school enrolments of families who remain at home. To achieve this objective, the data of the year 2009 from the World Bank (The World Bank Group, 2011), the Department of Health Services under the Ministry of Health (Department of Health Services, 2011), CBS (CBS, 2018), and Financial Comptroller General Office (Financial Comptroller General Office, 2011) have been utilized.

\section{Global discussion on remittances and social development}

The global trends in migration and remittance inflows have drawn attention of both researchers and policy makers. Taylor et al. (1996) state that as the households from the developing countries of regional and national economies become increasingly linked to labour markets in the developed world, policy makers and researchers tend to understand the economic effect of international migration on the regions that receive the remittances. The role of remittances in development continues to be an important issue for researchers and policymakers (Chami et al., 2005). Similarly, Brown (2006) states that the increasing volume of global remittances has impressed policymakers and social scientists alike. Now both the policy makers and social scientists are attracted towards the trends in migrations and thereby remittance inflows, and that trend has created enormous amount of theoretical and empirical literature. However, less is known about the effect of remittance on social development (Hu, 2013); and fewer researches for the consensus over the impacts of remittance have been carried out (Mansour et al., 2011). An important question which has attracted attention is how remittance is being spent and what possible implications of remittances on social development are.

Klugman (2009) has discussed about the relationship between remittance and social development; and it has stated that remittances are vital in improving the livelihoods of millions of people in developing countries. Similarly, a number of studies have examined the effect of remittances on social development where remittances have encouraged to spend more on not only consumption but also in human capital development (Hu, 2013; Mansour et al., 2011; Parida et al., 2015; Thapa \& Acharya, 2017). There are several other studies that have focused on the role of remittances in increased expenditure on health services (Anton, 2010; Wahba, 2015). All these studies have examined the effect of remittances on social development. Some other studies have confirmed the positive contribution of remittances to improving household welfare, living conditions ( $\mathrm{Hu}$, 2013; UNDP, 2009; Yang \& Choi, 2007) and increased education of the children (Jaquet et al., 2016; Thieme \& Wyss, 2005; Vogel \& Korinek, 2012). The positive contribution of remittance to social development has also been well recognized by the international organizations (International 
Organization for Migration, 2017; World Bank Group, 2018).

The theoretical and empirical literatures are vastly mixed and they offer no conclusive answer regarding the positive or negative impacts of remittances on social development. Siddiqui (2003) states that migration helps parents to afford their children's better educational opportunities but at the same time children's education is also affected because of their parents' absence. Therefore, it is evident that remittances have contributed positively to children's better education on the one hand, children's education has also suffered because of the absence of their mother and father on the other (Nepal Rastra Bank, 2012). Literatures suggest that migrant workers support their families through remittances but the families who remain at home often experience poorer mental health (Adhikari et al., 2011; Tachibana et al., 2019).

\section{Nepal's migration and remittance trend}

The absent population ${ }^{2}$ has been a major issue in demographic, social and economic aspects in Nepal. The absent population in 2011 (7.3\% of total population) has significantly increased compared to the number in 2001 census (3.2\% of total population). According to CBS (2014), most of the absent populations are the people of working age, of which the largest proportion is 15 to 24 years' age-groups. A total of 2.86 million labour permits were issued by the Department of Foreign Employment (DoFE) between 2012/13 and 2017/18 (DoFE, 2019). Due to the earthquake that hit Nepal in April 2015, there was a decrease in the number of labour permits in the year $2014 / 15$ to $2016 / 17^{3}$. The number of migrant labour permits issued dropped from 499,102 in $2014 / 15$ to 382,871 in $2016 / 17$. Nevertheless, this has again increased to 612,686 in $2017 / 18$. It shows how motivated Nepalese workers are for foreign employment and livelihood opportunities. However, this trend has created several challenges to the Government of Nepal in managing the huge outflow of labour migrants. Data from the Department of Foreign Employment suggests that the labour migrants have obtained permits to work in about 145 countries. Malaysia and Gulf Cooperation Council countries are the most attractive destinations. All the top-ten permits receiving districts of the country are located in the Tarai region ${ }^{4}$. The stream of migration was not planned but it evolved naturally. However, policies and acts executed by the Government played a role in favouring international migration especially emigration. Through policies, laws, institutions and programs, Government of Nepal is putting efforts on the management of migration governance. For instance, Government adopted National Labour Policy in 1999, Foreign Employment Act in $1985^{5}$ and Foreign Employment Policy in 2012 (Nepal Law Commission, 2019). Likewise, structural mechanisms are also in place. Ministry of Labour, Employment and Social Security is an apex body to govern labour administration and management (Ministry of Labour Employment and Social Security, 2019). Department of Foreign Employment and Foreign Employment Promotion Board have been established to ensure and promote safe and healthy working environment for the migrant workers (Department of Foreign Employment, 2019; Foreign Employment Promotion Board, 2019).

\footnotetext{
2 An individual absent from the household and gone abroad for more than six months before the census.

3 In Nepal, the new fiscal year starts from the middle of July, in general.

4 Tarai region is one of the ecological zones, the southern part of Nepal. Nepal is classified into three ecological zones, namely Mountain, Hill and Tarai.

5 The Foreign Employment Act was amended in 2007.
} 
As the number of labour migrants for foreign employment is increasing, so is the inflow of remittance. Remittance is a major source of foreign exchange earnings in many countries and same is the scenario in Nepal. Nepal's economy in the recent years has become remittance-based because of the continuous increase in the remittances in the country. In the year 2018 A.D., Nepal was one of the top remittance-receiving countries, as a share of gross domestic product (World Bank Group, 2019). Over the years both the amount of migration remittance inflows in US\$ and its proportion to GDP have increased (see Figure 1). The migrant remittance inflows into Nepal remained robust in 2018, rose by $16.4 \%$ and reached a new historic height of US\$ 8,064.35 million. With respect to remittance as a share of GDP, Nepal is not only leading the South Asia region but is also among the top recipient countries in the world. Nevertheless, remittance as a share of GDP has decreased by 3.36 percentage point between the year 2016 (31.21\%) and the year 2017 A.D. (27.85\%). However, the remittances in terms of US\$ still increased during the same period. In the case of Nepal, these substantial financial inflows can be utilized as a significant and influential resource to promote social development. At macro level, the upsurge in the flows of remittance might contribute to the overall development of the country. Likewise, at micro level, the households that receive remittances can also benefit from the increased household members' income, and can have better access to health and education facilities and improve the future prospects of their children.

Figure 1: Migrant remittance inflows (US\$ million and percent of GDP), $1993-2018$

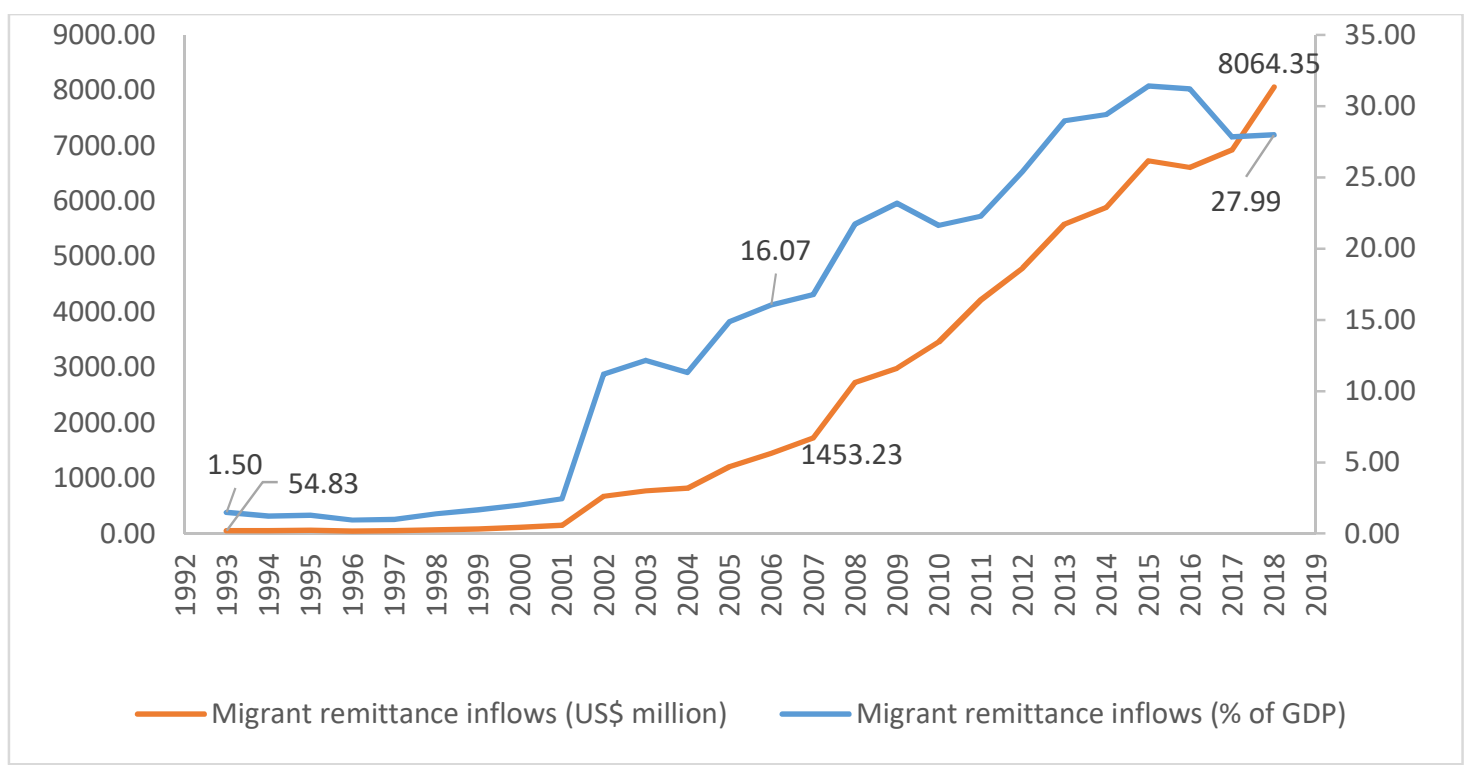

Adapted from The World Bank, 2018.

\section{Method}

While going through the literatures and empirical studies, mixed relationships between remittance and social development were found. In most of the cases, remittances have contributed to economic development whereas no clear-cut conclusions have been drawn regarding the 
relationship between remittance and social development (Brown, 2006; Chami et al., 2005; Taylor et al., 1996). In this regard, this study has proposed two hypotheses:

a) there is a positive relationship between remittance and improvement in health status of families who remain at home, and

b) there is a positive relationship between remittance and school enrolment.

\section{Model and variables}

The main objective of this study is to determine the effect of remittance on social development. Health and educational development are considered as the proxies of social development. Equation 1 has been used to analyse the impact of remittance (REM) on malnourishment (MAL).

$$
\log \mathrm{MAL}_{\mathrm{i}}=\beta_{0}+\beta_{1} \log \mathrm{REM}_{\mathrm{i}}+\epsilon_{\mathrm{i}}
$$

Where, log is logarithm, is error term, and are regression parameters.

Equation 1 uses 'malnourishment' one of the proxies of social development as a dependent variable and remittance as an independent variable. To obtain an unbiased estimate of causal effect in regression, the other independent variable was entered in Equation 1 as shown in Equation 2 below

$$
\log \mathrm{MAL}_{\mathrm{i}}=\beta_{0}+\beta_{1} \log \mathrm{REM}_{\mathrm{i}}+\beta_{2} \log \mathrm{GOE}_{\mathrm{i}}+\beta_{3} \log \mathrm{PUF}_{\mathrm{i}}+\epsilon_{\mathrm{i}} \text { (2) }
$$

Equation 2 adds value over Equation 1 by adding two independent variables named government expenditure (GOE) and population under five years of age (PUF) to see how the model reacts and whether the magnitude of relationship changes. Likewise, this study tries to add one more independent variable named population density in Equation 2. However, due to multicollinearity problem between the two independent variables: population density and government expenditure, the population density was dropped from the model. With the expectation of government expenditure being more relevant variable in analysing the relationship between remittance and malnourishment, population density was omitted. Development investments made by the government in various sectors can have significant influence on malnourishment (Benson, 2005; Arif et al., 2014). In this way, this study has tried to eliminate the omitted variable bias in the regression estimates.

Likewise, Equation 3 has been used to analyse the impact of remittance on primary school enrolment (PSE). It uses another proxy of social development: primary school enrolment, as a dependent variable and remittance and government expenditure as independent variables.

$$
\log \operatorname{PSE}_{\mathrm{i}}=\beta_{0}+\beta_{1} \log \mathrm{REM}_{\mathrm{i}}+\beta_{2} \log \mathrm{GOE}_{\mathrm{i}}+\epsilon_{\mathrm{i}}
$$

\section{Data and sources}

In an effort to assess the impact of remittance on development, disaggregated data for the year 2009 , by district ${ }^{6}$, from various sources have been used. Due to data unavailability of remittance

6 Earlier, there were 75 districts in Nepal. However, with the promulgation of the new constitution in 2015, Nepal now has 77 districts. This study uses data of 62 districts only, due to limited data availability on remittances. 
for more recent years, this study was bound to use the data only from the year 2009 A.D. Data on remittance by districts are acquired from Nepal Migration Survey $2009^{7}$ (The World Bank Group, 2011). Data on public spending by districts are obtained from the Consolidated Financial Statements for the fiscal year 2009/2010 A.D. published by Financial Comptroller General Office, Government of Nepal (Financial Comptroller General Office, 2011). Similarly, data on primary school enrolment by districts are obtained from Statistical Year Book Nepal published by CBS, National Planning Commission (National Planning Commission [NPC], 2017), Government of Nepal (CBS, 2018). Likewise, data on malnourishment by districts are obtained from Annual Report published by the Department of Health Services, Ministry of Health and Population, Government of Nepal (Department of Health Services, 2011).

\section{Results}

\section{Descriptive statistics}

Table 1 below provides summary statistics of the amount of remittances and the government expenditure including the number of malnourished children and primary school enrolment. The statistics reveal that there are great discrepancies in statistics across the districts. The average remittance received by 62 districts is 3.38 billion Nepalese rupees (NPR) and the average government expenditure at the district level is 3.02 billion NPR. The standard deviation of this government expenditure is 6.82 billion indicating that there is a considerable spread in government expenditure across districts. In the case of malnourishment, the mean value is 820.63 and in the case of primary school enrolment, the mean value is $71,512.18$ with the standard deviation of 33,602.62 point.

Table 1: Descriptive Statistics of the Variables Used in the Study

\begin{tabular}{llllc}
\hline \multirow{2}{*}{ Measure } & Variable & & \\
\cline { 2 - 5 } & REM (in billion, NPR) & GOE (in billion, NPR) & MAL & PSE \\
\hline Count & 62.00 & 62.00 & 62.00 & 62.00 \\
Mean & 3.38 & 3.02 & 820.63 & $71,512.18$ \\
Standard Deviation & 3.51 & 6.82 & 783.98 & $33,602.62$ \\
Maximum & 16.80 & 55.01 & $3,330.00$ & $155,489.00$ \\
Minimum & 0.10 & 0.75 & 17.00 & $11,058.00$ \\
\hline
\end{tabular}

\section{Regression Results}

Analysing descriptive statistics alone is not sufficient to examine the relationship between remittance and social development. Thus, in order to assess whether remittance has an impact on improvement in health status and school enrolment of children who remain at home, it is necessary to supplement descriptive statistics with a regression-based analysis. Again, I wish to mention briefly in one or two lines about what I was trying to do and find out. Before proceeding to hierarchical regression, I assessed Multicollinearity among the predictor variables. The Durbin-

7 National Migration Survey is a survey of 3,200 households and was conducted in the period May to September 2009 by the World Bank Group, 2011. 
Watson value indicated that there is no autocorrelation among the variables. In this way, the analysis of the properties of multiple regression indicated the need for further analysis. This study used a hierarchical multiple regression analysis to test the relationship among variables by creating two separate blocks. Remittance has been expected to be the main predictor. That is why, it has been entered into the first block, and government expenditure and population under five years have been entered into the second block. As stated earlier, population density was omitted from the model since it is found to be strongly correlated with the predictor, known as government expenditure $(r>.90)$.

Table 2 below presents the summary results of two-stage hierarchical multiple regression considering malnutrition as a dependent variable. Model 1 refers to the first stage in the hierarchy when only remittance is used as a predictor. Model 2 refers to the final model where remittance, government expenditure and population under five years are used as predictors. The hierarchical multiple regression revealed that, at stage one, remittance did not contribute significantly to the regression model. Introducing the government expenditure and population under five years at stage two explained an additional $36 \%$ variation in malnourishment, $R^{2}=.39, \Delta R^{2}=.36, F(3,58)=$ $12.37, p=<.001$. Likewise, the variance predicted by the regression model is acceptable. However, remittance as well as government expenditure were still found to be insignificant in predicting malnourishment, $t(61)=-1.89, p>.05$ and $t(61)=0.76, p>.05$, respectively. Nevertheless, population under five years was found to be significant in predicting malnourishment, $t(61)=4.44, p<.001$. Further summary of hierarchical regression analysis for variables predicting malnourishment is presented in Table 2 below.

Table 2: Summary of Hierarchical Regression Analysis for Variables Predicting Malnourishment

\begin{tabular}{|c|c|c|c|c|c|}
\hline Variable & $b$ & & $T$ & $R^{2}$ & $\Delta R^{2}$ \\
\hline Model 1 & & & & .03 & \\
\hline Log REM & 0.17 & .17 & 1.31 & & \\
\hline Model 2 & & & & $.39 * *$ & .36 \\
\hline Log REM & -0.24 & -.23 & -1.89 & & \\
\hline Log GOE & 0.17 & .09 & 0.67 & & \\
\hline Log PUF & 1.20 & $.69 * * *$ & $4.44 * * *$ & & \\
\hline
\end{tabular}

Table 3 given below presents the summary results of two-stage hierarchical multiple regression considering primary school enrolment as a dependent variable. Model 1 refers to the first stage in the hierarchy when only remittance is used as a predictor. Model 2 refers to the final model where remittance and government expenditure are used as predictors. The hierarchical multiple regression analysis revealed that, at stage one, remittance contributed significantly to the regression model $(F(1,60)=22.10, p<.001)$ and accounted for $26.9 \%$ of the variation in primary school enrolment. Introducing the government expenditure variable at stage two explained an additional $23.8 \%$ of the variation in primary school enrolment and this change in $R^{2}$ was significant, $R^{2}=.51, \Delta R^{2}=.24$, $F(2,59)=30.41, p<.001$. The regression has a good model fit and has the ability to predict the outcome variable. The $b$-values tell us about the relationship between primary school enrolment 
and each predictor. Since both values are positive, it can be ascertained that there is a positive relationship between the predictor and outcome variables. As the remittance increases, primary school enrolment increases; and as government expenditures increase, so does the primary school enrolment. These relationships suggest that each predictor affects the dependent variable if the effect of the other predictor is held constant. The $b$-value for remittances is 0.13 . This indicates that as remittance increases by one unit, primary school enrolment also increases by 0.13 unit. Values of both variables were converted to base ten logarithm; therefore, it indicated that for every one additional unit of remittance received meant an additional 0.13 unit students got enrolled in primary school. This is applicable only if the effects of government expenditure are held constant.

Table 3: Summary of Hierarchical Regression Analysis for Variables Predicting Primary School Enrolment

\begin{tabular}{|c|c|c|c|c|c|}
\hline Variable & $b$ & & $t$ & $R^{2}$ & $\Delta R^{2}$ \\
\hline Model 1 & & & & $.27^{* * *}$ & \\
\hline Log REM & 0.13 & $.41^{* *}$ & $4.70 * * *$ & & \\
\hline Model 2 & & & & $.51 * * *$ & .24 \\
\hline Log REM & 0.13 & $.35 *$ & $2.64 *$ & & \\
\hline Log GOE & 0.46 & $.48 * * *$ & $5.34 * * *$ & & \\
\hline
\end{tabular}

\section{Discussions}

The aim of this study was to investigate the relationship between remittance and social development, considering primary school enrolment and malnutrition as its proxies. The results of this study supported the prediction of significant positive relationship between the independent variables which were: remittances and government expenditure, and the dependent variable: primary school enrolment. Remittance was found to have an insignificant relationship with nutritional status of family who remain at home.

\section{Health development}

Finding of this study with insignificant relationship between remittance and health is inconsistent with past findings (Anton, 2010; Wahba, 2015). Nevertheless, when the effects of government expenditure and remittance were controlled, population under five years was a significant positive predictor of malnourishment. This indicated that districts having greater number of children under five years have greater number of malnourished children. This is true because there is wider variation in rates of malnourishment throughout Nepal. Districts like Bara, Sarlahi and Rautahat have the highest number of malnourished children (Department of Health Services, 2011). Although, the networks of health institutions providing primary health care services have been increasing across the districts of Nepal, the child undernourishment is still intolerable. Micronutrient supplementation program of Nepal is globally recognized as a successful program, but undernourishment among children remains a serious public health issue.

As discovered by this study, the insignificant relationship between remittance and malnourishment is a surprising finding to discuss. It indicated that remittance is not being effective in significantly 
reducing malnourishment. This was against the assumption that the increased income resulting from remittance alleviates household budget constraints and expands choices for financial decision-making. This may have been due to the health related behaviour and practices of the Nepalese people. Usually, the Nepalese people are not used to doing regular medical check-ups to keep track of their health. That is even worse in rural and geographically remote areas. For example, Ministry of Health Nepal, New Era \& ICF (2017) state that the percentage of children with fever for whom treatment or advice is sought is higher in urban areas than in rural areas (82.5\% versus $76.1 \%)$. Likewise, regarding children suffering from diarrhea, those residing in the hill zone (45\%) are much less likely to be taken to a health facility or health service-provider for advice or treatment than those in the Tarai zone (74\%). Children are not brought to health service providers until they are severely ill. That is why, many of the malnourishment cases go unreported and unaddressed. Unless a malnourished child suffers from any other disease and is brought to the nearby health institution, the statistical record of the malnourished child remains unknown and that lasts until the death of that child.

Another possible reason behind the insignificant relationship between remittance and malnourishment may be due to investment of the larger proportion of remittance in children's education. With additional cash income from remittances, more migrant households were found to be investing in their children's education compared to non-migrant households (Centre for the Study of Labour and Mobility, 2017). Generally, health is considered as a consumption activity whereas education is considered as an investment activity. Hence, investment in education gets higher priority than investing in health. Nepal Rastra Bank (2012) states that remittance-receiving households spend nearly six thousand rupees more than the non-receiving households, whereas in the case of health expenditure it is only three thousand more. In the FY $2009-2010$ A.D., the share of government expenditure made on education was $17.76 \%$ and that on health was $6.45 \%$. Likewise, in the FY 2016/17 almost 13\% of total expenditure was allocated for the education sector whereas only about 5\% in the health sector (Financial Comptroller General Office, 2016).

Likewise, another plausible cause behind the insignificant relationship between remittance and malnourishment may be due to the socio-economic background of those who migrated. Centre for the Study of Labour and Mobility (2017) states that migration has benefitted migrants but the cost and benefit of migration vary by socio-economic background. World Bank Group (2011) states that migrants often pay higher fees to manpower agencies and the higher interest rates on these informal loans magnify the overall cost of migration. People with low socio-economic background have lower financial capacity for self-financed migration; and that is why, such households, having poor economic status to send family members for foreign employment, may have more malnourished children at home.

\section{Educational development}

The second hypothesis assumed that there is a relationship between remittance and educational development. Consistent with the past research findings (Hu, 2013; Mansour et al., 2011; Parida et al., 2015; Thapa \& Acharya, 2017), the hypothesis that remittances and school enrolment are significantly related was supported. Emperical results show that the magnitude of remittance has an impact on eduactional enrolment which is substantially large in number. The results are robust and unaffected by multicollinearity. 
The current findings indicate that remittance and government expenditure are also significant positive predictors of primary school enrolment; and the findings also indicate that although basic education is free and compulsory in Nepal, the overall household income is also a determining factor in the educational enrolment. When the effects of government expenditure were controlled, remittance remained a significant predictor of primary school enrolment. This supports the claim that receiving remittance encourages the Nepalese families to enrol their children in primary level education. Government expenditure is also seen as an equally important and significant positive predictor of educational enrolment.

According to the findings of this study, the relationship between remittance and educational enrolment needs to be defined considering several mixed factors. Remittance, as an additional source of income, has provided an opportunity of support to the family members remaining at home. This additional source has helped the households to reduce the household budget constraints and has opened up new spending opportunities. It has expanded the households' choices of educating their children. Results from this study suggest that the role of remittance in determining the educational enrolment is higher than the role of government expenditure, because remittance alone accounted for $26.90 \%$ of the variation in primary school enrolment out of the total variation (50.70\%).

Undoubtedly, essential services like basic education cannot be provided without establishing schools and recruiting qualified teachers. The money invested is of little use if there are no schools where children can get enrolled and no quality education in those schools. In Nepal, institutional schools and their services are abundantly available, especially in urban and peripheral areas, but are very expensive. In the case of education services of the government of Nepal, there is either inaccessibility for remote areas' children or their quality of education is compromised (Koirala, 2015). The lowest number of primary school enrolment is from Mugu, Myagdi and Jumla districts (CBS, 2018). The two districts out of the three are from remote geographical areas. Moreover, due to increasing marketization of the facilities in the institutional facilities and the declining quality of public schools' education, the parents are left without viable choices for educating their children. Enroling children in better public or institutional schools not only requires more money but also compels the parents to migrate from the place of their origin in the search of better schools; and this could be possible only for those households that receive remittances.

Overall financial wellbeing of a household also plays a key role in children's enrolment in education. The households with poor financial background may not have enough to spend on their children's education. Since financially poor households' parents have to earn bread and butter for their household members, the school-going children also have primary responsibilities of household chores such as preparing food, babysitting, water fetching, herding cattle and so on. On the other hand, unlike poor families, the remittance receiving households have more choices and flexibility to spend income on their children's education.

\section{Conclusion}

Policies and acts executed by the government of Nepal have played a key role in favouring international migration especially emigration. Remittance is a major source of foreign exchange earning in Nepal and its economy in the recent years has become remittances based. However, 
proper utilization of such transfers can only leverage the development impact. In this study, I examined the effects of the remittances on the social development using district-wise disaggregated data from secondary sources.

After carefully selecting the variables and analysing their relationship, I found that there is an insignificant relationship between remittance and health development. The indication that remittance is not being effective in significantly reducing malnourishment is due to the investment of the larger proportion of remittance in children's education and socio-economic background of those who migrated. On the other hand, the results have shown that the remittance plays a positive role in school enrolment which contradicts with the argument that remittance has an impact on increased consumption and thus do not contribute to development. Nevertheless, the findings also indicate that remittance is beneficial to migrants and the household members who are at home, but according to the same findings the benefits from remittances have varied by district.

The study has found out that receiving remittance encourages the Nepalese migrants to enrol their children in primary level education. Likewise, government expenditure was equally important to raise children's educational enrolment status. Making basic education free and compulsory alone may not help the country like Nepal to achieve the goal of universal education. Alleviating household budget constraints by increasing financial wellbeing is equally crucial in determining educational enrolment. For the long-term development efforts, the government should be encouraged to direct and utilize remittances and migrant workers in productive investments like small businesses and projects that generate jobs and help the nation's economy to sustain. This can be done by creating investment opportunities for the remittances so that the benefits of migration become widespread and not only for the migrants and their families but also for the society and the nation as a whole. Furthermore, efforts in utilizing the knowledge, skills and technology gained by the returnee-migrants at home country is equally important.

\section{Limitations and possible extensions}

There are several ways in which further studies can be extended in the future considering a few research limitations observed in this research. An additional effort or direction to extend this study could be to explore the relationship between remittance and social development by employing new dataset. The district level remittances data for Nepal is scarce. So, World Bank's (2011) data was the only available option to achieve the objective of this study. Particularly, analysing this sort of relationship using latest panel data can help to draw more precise conclusions. Due to unavailability of the district level data on remittances, except for the year 2009, this study could not consider more variables that could have an effect on malnutrition and primary education. So, further studies can be carried out adding more relevant variables in the regression model. 


\section{References}

Adhikari, R., Jampaklay, A., \& Chamratrithirong, A. (2011). Impact of children's migration on health and health care-seeking behaviour of elderly left behind. BMC Public Health 11(1), 1-8. https://doi. org/10.1186/1471-2458-11-143

Anton, J. I. (2010). The impact of remittances on nutritional status of children in Ecuador. The International Migration Review, 44(2), 269-299. https://doi.org/10.1111/j.1747-7379.2010.00806.x

Arif, G. M., Farooq, S., Nazir, S., \& Satti, M. (2014). Child malnutrition and poverty: The case of Pakistan. The Pakistan Development Review, 53(2), 99-118.

Benson, T. (2005). An assessment of the causes of malnutrition in Ethiopia. International Food Policy Research Institute.

Brown, S. S. (2006). Can remittances spur development? A critical survey. International Studies Review, 8(1), 55-75.

Central Bureau of Statistics. (2011). Nepal living standards survey 2010/11: Statistical report volume II. Author.

Central Bureau of Statistics. (2014). Population monograph of Nepal: Volume I. Author.

Central Bureau of Statistics. (2018). Statistical year book Nepal 2017. Author.

Centre for the Study of Labour and Mobility. (2017). Labour migration and the remittance economy: The socio-political impact. Author.

Chami, R., Fullenkamp, C., \& Jahjah, S. (2005). Are immigrant remittance flows a source of capital for development? IMF Staff Papers, 52(1), 55-81.

Department of Foreign Employment, Ministry of Labour, Employment and Social Security. (2019, August 19). About us: Introduction. https://dofe.gov.np/

Department of Health Services. (2011). Annual report 2066/67. Department of Health Services.

Devkota, J. (2014). Impacts of migrants' remittances on poverty and inequality in Nepal. Forum of International Development Studies, 44(1), 36-53.

Dornates, C. A., Georges, A., \& Pozo, S. (2010). Migration, remittances, and children's schooling in Haiti. The Annals of the American Academy of Political and Social Science, 630, 224-244.

Field, A. (2005). Discovering statistics using SPSS. SAGE Publications.

Financial Comptroller General Office. (2011). Consolidated financial statements fiscal year 2009/2010. Author.

Financial Comptroller General Office. (2016). Consolidated financial statements fiscal year 2016/17. Author.

Foreign Employment Promotion Board. (2019, August 19). About us. http://www.fepb.gov.np/

$\mathrm{Hu}, \mathrm{F}$. (2013). Does migration benefit the schooling of children left behind? Evidence from rural northwest China. Demographic Research, 29(1), 33-70.

Inter-Agency and Expert Group on Sustainable Development Goal Indicators. (2016). Report of the interagency and expert group on sustainable development goal indicators https://unstats.un.org/unsd/ statcom/47th-session/documents/2016-2-IAEG-SDGs-Rev1-E.pdf

International Fund for Agricultural Development. (2017). Remittances, investments and the sustainable development goals. Author.

International Organization for Migration. (2017). World migration report 2018. Author.

Jaquet, S., Shrestha, G., Kohler, T., \& Schwilc, G. (2016). The effects of migration on livelihoods, land management, and vulnerability to natural disasters in the Harpan watershed in western Nepal. Mountain Research and Development, 36(4), 494-505.

Koirala, A. (2015). Debate on public and private schools in Nepal. International Journal of Management and Social Sciences, 2(1), 3-8.

Mansour, W., Chaaban, J., \& Litchfield, J. (2011). The impact of migrant remittances on school attendance and education attainment: Evidence from Jordan. The International Migration Review, 45(4), 812-851.

Ministry of Health, Nepal (2017). Nepal demographic and health survey. Author. 
Ministry of Labour and Employment. (2016). Labour migration for employment: A status report for nepal 2014/15. Author.

Ministry of Labour, Employment and Social Security. (2019, August 19). About us: Function. https://moless. gov.np/

National Planning Commission. (2017). Nepal's sustainable development goals - Status and roadmap: 20162030. https://www.npc.gov.np/images/category/SDG_Status_and_Roadmap_(2016-2030).pdf

Nepal Rastra Bank. (2012). Impact evaluation of remittances: A case study of Dhanusha district. Nepal Rastra Bank.

Nepal Law Commission. (2019, August 15). Existing law: Policies. http://www.lawcommission.gov.np/

Pant, B. (2011). Harnessing remittances for productive use in Nepal. Economic Review, 23(1), 1-20. https:// www.nrb.org.np/ecorev/index.php?vid=23-1

Parida, J. K., Mohanty, S. K., \& Raman, R. K. (2015). Remittances, household expenditure and investment in rural India: Evidence from NSS data. Indian Economic Review, New Series, 50(1), 79-105.

Ratha, D. (2007). Leveraging Remittances for Development. World Bank.

Siddiqui, T. (2003). Migration as a livelihood strategy of the poor: The Bangladesh case. https://childhub.org/en/ system/tdf/library/attachments/siddiqui_03_mig_bangladesh_0408. pdf?file=1\&type=node\&id=18156

Tachibana, T., Goto, R., Sakurai, T., Rayamajhi, S., Adhikari, A., \& William H. D. (2019). Do remittances alleviate negative impacts of disaster on mental health? A case of the 2015 Nepal earthquake. Social Science and Medicine 238(1), 1-10. https://doi.org/10.1016/j.socscimed.2019.112460

Taylor, J. E., Arango, J., Hugo, G., Kouaouci, A., Massey, D. S., \& Pellegrino, A. (1996). International migration and national development. Population Index, 62(2), 181-212.

Thapa, S., \& Acharya, S. (2017). Remittances and household expenditure in Nepal: Evidence from crosssection data. Economics, 5(16), 1-17.

The World Bank. (2018, December). Data: Data Help Desk. https://datahelpdesk.worldbank.org/ knowledgebase/articles/906519-world-bank-country-and-lending-groups

The World Bank. (2019, June 21). Data: The World Bank. https://data.worldbank.org/country/ nepal?view=chart

The World Bank Group. (2011). Large-scale migration and remittance in nepal: Issues, challenges, and opportunities. Not Stated: Poverty Reduction and Economic Management Sector Unit: South Asia Region.

Thieme, S., \& Wyss, S. (2005). Migration patterns and remittance transfer in Nepal. International Migration, 43(5), 59-98.

Klugman, J. (2009). Human development report 2009-Overcoming Barriers: Human Mobility and Development (October 5, 2009). United Nations Development Programme.

Vogel, A., \& Korinek, K. (2012). Passing by the girls? Remittance allocation for educational expenditures and social inequality in Nepal's households 2003-2004. The International Migration Review, 46(1), 61-100.

Wahba, J. (2015). Selection, selection, selection: The impact of return migration. Journal of Population Economics, 28(3), 535-563.

World Bank Group 2018. Migration and remittances: Recent developments and outlook, Author.

World Bank Group. (2019). Migration and remittances: Recent developments and outlook. Author.

Yang, D., \& Choi, H. (2007). Are remittances insurance? Evidence from rainfall shocks in the Philippines. The World Bank Economic Review, 21(2), 219-248. 